\title{
Konstruksi Pembelajaran Sejarah Kontekstual Melalui Pendekatan Regresif Model Problem Based Learning
}

\author{
Putu Adi Sanjaya \\ SMA Negeri 2 Kuta \\ Email: adisanjaya.pt@gmail.com
}

\begin{tabular}{l}
\hline Artikel info \\
\hline \multicolumn{2}{c}{ Keywords: } \\
Pendekatan regresif, \\
$\begin{array}{l}\text { based learning, } \\
\text { kontekstual }\end{array}$
\end{tabular}

\begin{abstract}
Abstrak. Pembelajaran sejarah selama ini belum melatih kemampuan berpikir kritis-analitis, kemadirian dan kemampuan menyelesaikan permasalahan kontekstual yang ada di sekitar siswa. Cukup banyak kelemahan dan kekurangan pelajaran dan pembelajaran sejarah yang dilakukan dan disajikan selama ini. Diperlukan suatu pendekatan pembelajaran yang mampu mengintegrasikan kemampuan berpikir kritis-analitis dalam penyelesaian masalah yang bersifat kontekstual. Pembelajaran sejarah yang biasanya dilakukan secara progresif kini dapat dilakukan dengan pendekatan regresif. Pendekatan regresif yang diterapkan dengan model Problem Based Learning secara ideal dapat meningkatkan kemampuan siswa dalam menyelesaikan kontekstualitas peristiwa. Perancangan desain pembelajaran sejarah dengan pendekatan regresif dengan model PBL diawali dengan penyusunan rencana pembelajaran, penyusunan materi ajar, dilanjutkan dengan perancangan kegiatan pembelajaran berbasis masalah (PBL), dan diakhiri dengan penilaian otentik. Pada dasarnya guru dituntut harus lebih kreatif dan adaptif dalam menyajikan pembelajaran agar pembelajaran sejarah.
\end{abstract}

\begin{abstract}
So far, history learning has not trained students' critical-analytical thinking skills, independence and the ability to solve contextual problems around students. There are quite a lot of weaknesses and shortcomings in the history lessons and learning that have been carried out and presented so far. It takes a learning approach that is able to integrate criticalanalytical thinking skills in solving contextual problems. History learning, which is usually done progressively, now can be done using a regressive approach. The regressive approach applied with the Problem Based Learning model ideally can improve students' ability to solve the contextuality of events. The design of the history learning design using a regressive approach with the PBL model begins with the preparation of a lesson plan, the preparation of teaching materials, followed by the design of problem-based learning activities (PBL), and ends with an authentic assessment. Basically, teachers are required to be more creative and adaptive in presenting lessons for history learning.
\end{abstract}

Coresponden author:

Email: adisanjaya.pt@gmail.com

\section{A. PENDAHULUAN}

Berbagai perkembangan dalam yang berkaitan secara langsung maupun tidak langsung dengan pendidikan dewasa ini membuat para pemegang kebijakan dan praktisi pendidikan harus senantiasa berbenah dan meningkatkan inovasi dalam proses pembelajaran. Berbagai 
perkembangan di bidang teknologi informasi ditambah dengan perkembangan teori pembelajaran yang relevan dengan kondisi dan situasi saat ini menghasilkan berbagai pendekatan, model, strategi, tipe dan model pembelajaran yang memiliki ciri khas dan karakteristik yang berbeda-beda. Pemanfaatannya pun dapat diimplementasikan pada hampir semua mata pelajaran dengan beberapa prinsip penyesuaian pada kompetensi dasar, indikator atau materi pokok pembelajaran.

Pendidikan sebagai sarana penyalur ilmu pengetahuan (transfer knowledge) secara tidak langsung harus memiliki sistem yang dapat mendukung bagi terselenggaranya kegiatan tersebut. Era disrupsi ini memberikan kemudahan bagi kegiatan akses dan transfer pengetahuan dalam dunia pendidikan (Wisnu \& SN4JPSFISUNP2019, 2019). Hal tersebut salah satunya dibuktikan dengan adanya pemanfaatan teknologi yang cukup massif di dalam penyelenggaraan pendidikan pada era revolusi industry 4.0 sekaligus terjadinya krisis kesehatan dengan terjadinya wabah pandemi Covid-19 hampir di seluruh dunia. Sejak kemunculan pertamanya di Indonesia pada 2 Maret 2020 sebanyak 2 kasus (Nugraheny, 2020), virus ini secara langsung maupun tidak langsung dihadapkan pada sejumlah permasalahan dalam berbagai aspek kehidupan. Mulai dari aspek utama, yaitu kesehatan dengan peningkatan kasus yang hingga saat ini sangat tinggi, aspek ekonomi seperti penutupan atau pembatasan kegiatan perekonomian masyarakat serta keterbatasan logistik, aspek budaya seperti berubahnya pola hidup akibat kewajiban menerapkan protocol kesehatan ketat, serta aspek pendidikan. Pada aspek terakhir ini, pendidikan merasakan dampak yang sangat kompleks pula seperti pembatasan pertemuan pembelajaran yang diganti dengan kegiatan belajar dari rumah (BDR), Pembelajaran Jarak Jauh (PJJ) dimana guru, siswa dan orangtua "dipaksa" untuk melakoni semua proses itu (kendatipun sebagian besar belum siap), hingga hal-hal yang bersifat psikologis seperti tingkat stress, kejenuhan, dan berbagai permasalahn lainnya yang tak terduga.

Dalam menghadapi situasi di atas, sepertinya masyarakat Indonesia belum mempersiapkan generasinya pada upaya untuk siap dalam menghadapi permasalahan. Upaya tersebut seharusnya sudah dapat dilakukan sejak dini melalui proses pendidikan dari jenjang pendidikan dasar hingga pendidikan tinggi. Peningkatan kompetensi yang diperlukan saat ini salah satunya adalah dalam hal kemampuan memecahkan masalah melalui keterampilan berpikir kritis. Berbagai upaya dan inovasi dilakukan oleh pendidik untuk mencapai tujuan tersebut.

Masa pandemi COVID-19 benarbenar telah mengubah praktek pembelajaran secara drastis menjadi pembelajaran yang berbasis kepada kemandirian belajar peserta didik dan pemanfaatan teknologi informasi komunikasi menjadi lebih utama. Pendidikan elektronik (e-education) dan pembelajaran elektronik (e-learning) dengan sarana internet benar-benar berjalan sepenuhnya karena didorong situasi pandemi (Pujilestari, 2020). Sejalan dengan hal tersebut pembelajaran sejarah sebagai salah satu mata pelajaran wajib pada jenjang SMA tentu harus mampu beradaptasi sesuai dengan situasi yang terjadi (Amboro, 2019). Paling tidak siswa mampu menggunakan kompetensi yang didapat dan dipahaminya melalui belajar sejarah untuk menghadapi permasalahan dan beradaptasi dengan situasi yang terjadi pada saat ini. Dalam pengembangannya pembelajaran sejarah harus mampu menyajikan kontekstualitas pembelajaraan yang disiapkan dengan memberikan keterampilan menghadapi permasalahan saat ini melalui pengalamanpengalaman sejarah sejenis yang pernah terjadi pada masa lampau.

Pembelajaran sejarah meskipun secara materi membahas tentang peristiwa yang telah terjadi pada masa lampau, akan tetapi sesungguhnya saat ini peristiwa yang akan menjadi sejarah pada masa yang akan datang sedang terjadi. Dalam sejarah dikenal adanya pola gerak sejarah yang dapat 


\section{3 | Jurnal Candra Sangkala}

berulang. Oleh karena itu konteksualitas pembelajaran sejarah menjadi suatu tantangan yang harus direspon dengan optimal oleh guru sejarah. Pendekatan sejarah seperti inilah yang disebut dengan pendekatan regresif.

Pendekatan regresif menjadi menarik digunakan sebagai pendekatan pembelajaran sejarah saat ini mengingat pendekatan progresif (kebalikan dari pendekatan regresif) hanya mampu menarik keunggulankeunggulan dan kebesaran peristiwa sejarah masa lampu untuk diketahui pada masa sekarang tanpa mampu memberikan solusi dari permasalahan yang dihadapi saat ini. Pendekatan regresif menawarkan desain pembelajaran dimana siswa dihadapkan pada permasalahan yang kontekstual dan menggunakan pemahaman sejarah yang sejenis sebagai suatu bentuk penelusuran solusi pemecahan masalahnya.

Berkaitan dengan latar belakang di atas, perlu kiranya dirumuskan beberapa hal yang menjadi permasalahan dan perlu dibahas sebagai suatu solusi, antara lain : 1) Bagaimana pendekatan regresif dalam memecahkan permasalahan kontekstualitas sejarah?; 2) Bagaimana desain pembelajaran dengan pendekatan regresif model problem based learning dalam pembelajaran materi sejarah kontekstual?. Tulisan ini dikaji dengan metode analisis kepustakaan, dimana hasil pembahasan diupayakan dapat menjadi suatu solusi mengenai model pendekatan pembelajaran sejarah yang solutif dan bersifat kontekstual dalam menghadapi permasalahan kehidupan masyarakat saat ini.

\section{B. PEMBAHASAN}

\section{Pendekatan Regresif dalam Kontekstualitas Pembelajaran Sejarah}

Secara sinkronik sejarah dapat membahas suatu objek secara komprehensif dalam multiperspektif dengan mengabaikan garis waktu secara kronologis. Sejarah dapat membahas mengenai peristiwa masa lalu yang memiliki kesamaan pola peristiwa dengan permasalahan yang dihadapi pada masa kini. Hal ini menjadi penting untuk menempatkan peristiwa sejarah secara kontekstual karena kebermaknaan dalam pembelajaran sejarah dapat dibangun. Seperti yang diungkapkan oleh Swantoro dalam bahasa Belanda "In het heden ligt het verleden, in het nu wat komen zal" bahwa "di masa kini terletak masa lalu, di masa sekarang terkandung masa depan", dan sesungguhnya ini menjelaskan bahwa sejarah memang selalu aktual (Swantoro, 2016).

Gambaran di atas memberikan suatu peluang bagi sejarah di dalam pengembangannya di dalam proses pembelajaran. Pengembangan yang sesuai adalah melalui desain pendekatan pembelajaran regresif yang lebih menekankan "alur mundur" dalam metode bahasannya. Pembelajaran sejarah dengan dasar "pemecahan masalah kekinian" mungkin dianggap tidak umum dilakukan di sekolah. Pembelajaran sejarah dengan pola "pemecahan masalah kekinian" merupakan pembelajaran sejarah yang menjadikan materi-materi dan konsep sejarah sebagai bagian integral dalam mengatasi masalahmasalah sosial masyarakat kekinian dewasa ini, namun dengan berpandangan faktor historis. Pembelajaran model demikian dapat dikatakan sebagai alternatif menantang bagi siswa dan guru. Model pembelajaran sejarah yang dilaksanakan bahkan dapat dikatakan "regresi" dari proses pembelajaran sejarah yang umum. Jika pembelajaran sejarah yang umum dilaksanakan dimulai dari materi masa lalu menuju masa kini, maka dalam pembelajaran sejarah melalui pemecahan masalah kekinian, maka proses mengajarkan secara "terbalik", yaitu mengajarkan materimateri sejarah yang berangkat dari "masa kini " menuju "masa lalu" (Wisnu \& SN4JPSFISUNP2019, 2019).

Pembelajaran sejarah yang lebih bermakna dapat dilakukan dengan memulai menggunakan model pembelajaran sejarah yang dimulai dari persoalan masa kini. Selain lebih bermakna pembelajaran sejarah juga akan lebih bersifat aplikatif daripada pembelajaran sejarah yang telah dilakukan pada umumnya. Pendekatan pembelajaran 
sejarah tersebut bukanlah diawali dari pengajaran materi-materi atau konsepkonsep sejarah yang pada umumnya disajikan di buku-buku teks, namun lebih cenderung diawali dari permasalahanpermasalahan sosial konkret yang muncul di sekitar siswa untuk kemudian ditarik ke belakang terhadap latar belakang historis yang menyebabkan munculnya permasalahan tersebut. Atau dalam aspek ini posisi historis (materi sejarah) sebagai gambaran penjelasan-penjelasan suatu fenomena masalah-masalah sosial yang muncul pada masa kini.

Penerapan pendekatan regresif dalam pembelajaran sejarah akan lebih aplikatif dan bermakna ketika disajikan dengan model pembelajaran berbasis masalah (Problem Based Learning), karena siswa diajak untuk mampu memahami dan mencarikan solusi terhadap kontekstualitas permasalahan berdasarkan pemahaman sejarah masa lalu. Cukup banyak fenomena kontekstual yang terjadi di sekitar siswa yang dapat dibahas melalui pendekatan regresif. Beberapa di antaranya adalah pandemic covid-19, kebijakan impor gula yang menempatkan Indonesia sebagai importer gula terbesar di dunia pada tahun 2017/2018, berbagai peristiwa terorisme, radikalisme, dan gerakan separatisme di Indonesia, krisis ekonomi, penanganan kasus korupsi, dan lain sebagainya. Sebagai contoh pada fenomena kebijakan ekonomi yang menempatkan Indonesia sebagai Negara pengekspor gula terbesar di dunia dua tahun lalu, padahal pada masa Hindia-Belanda khususnya pada masa cultuur stelsel dulu Indonesia (Pulau Jawa saja) sudah menjadi daerah pengekspor gula terbesar di dunia. Untuk mengkaji kontekstualitas peristiwa tersebut melalui pendekatan regresif langkah yang dapat dilakukan dalam pembelajaran sejarah antara lain sebagai berikut.

1) Siswa diberikan suatu topik masalahmasalah sosial kekinian yang berhubungan atau masalah yang terkait dengan aspek-aspek kesejarahan.
2) Siswa lalu dapat diminta secara berkelompok untuk mengidentifikasi permasalahan tersebut, seperti faktorfaktor apa yang megakibatkan munculnya suatu permasalahan.

3) Siswa diminta untuk mengkaji/menganalisis, serta memecahkan permasalahan yang muncul di dalam topik dengan berpedoman pada aspek-aspek historis.

4) Siswa diharuskan mengungkapkan gagasan, argumen serta kesimpulan berdasarkan sumber-sumber sejarah atau literatur terkait

5) Siswa menjelaskan solusi dari pemecahan masalah dari munculnya problem.

Melalui topik masalah kekinian tersebut, maka siswa diajak untuk merefleksikan diri terkait topik masalah sosial tersebut dengan menarik pemahaman siswa menuju masa lampau di Abad $18 \mathrm{M}$, yaitu ketika wilayah Indonesia masih di bawah kolonialisme Belanda. Siswa diminta membuat perbandingan terkait kondisi perkembangan industri gula saat ini (tahun 2018-2020) dengan perkembangan industri gula di jaman kolonial (abad 18 M). Siswa dapat diberikan pemahaman objektif melalui pertanyaan-pertanyaan yang menantang. Beberapa pertanyaan pilihan menantang seperti berikut ini.

1) Pada masa kolonial (penjajahan Belanda) di abad $18 \mathrm{M}$, wilayah nusantara (Jawa) mampu menjadi produsen dan pengekspor gula terbesar di dunia, namun demikian mengapa saat ini negara kita (Indonesia) justru melakukan hal sebaliknya, yaitu mengimpor gula dari luar negeri ?

2) Permasalahan atau kendala apa yang kalian temukan sehingga pemerintah Indonesia sekarang justru mengimpor gula dari luar negeri ?

3) Merujuk kondisi masa lalu, bagaimanakah strategi pemerintah 
kolonial Belanda pada masa itu sehingga mereka mampu menjadikan wilayah nusantara (Jawa) sebagai penghasil gula terbesar di dunia?

4) Apa upaya-upaya yang dapat kalian lakukan atau sumbangan apa yang dapat kalian berikan bagi pemerintah dan masyarakat untuk membangkitkan industri gula di tanah air saat ini agar mampu berjaya kembali seperti di abad $18 \mathrm{M}$ ?

Pada pembahasan mengenai pandemic Covid-19 saat ini misalnya, siswa dapat dibimbing dan diajak untuk melakukan pembelajaran sejarah dengan pendekatan regresif melalui pertanyaan-pertanyaan menantang berikut ini.

1) Pada masa perjalanan sejarah Indonesia dan dunia, wabah penyakit apa saja yang terjadi dan mempengaruhi masyarakat secara makro?

2) Apa saja dampak yang ditimbulkan dari masing-masing wabah penyakit tersebut bagi kehidupan masyarakat yang terdampak?

3) Merujuk pada kondisi masa lalu, bagaimana upaya masyarakat dan pemerintah saat itu dalam melakukan penanganan baik secara preventif, persuasif maupun represif?

4) Berdasarkan pengalaman masa lalu, solusi pemikiran apa yang bisa kalian tawarkan dalam penanganan pandemi Covid-19 yang melanda Indonesia dan dunia saat ini?

Di atas adalah dua contoh kontekstualitas peristiwa yang dihadapi oleh masyarakat saat ini, yang melalui pendekatan regresif guru membimbing siswa menelusuri masa lalu khususnya pada peristiwa yang memiliki kesamaan pola dan jenis dengan model pemecahan masalah. Melalui stimulus pertanyaan-pertanyaan seperti bentuk di atas, siswa dapat dibimbing menuju latar belakang aspek historis guna memecahkan masalah-masalah sosial kekinian di sekitar siswa. Melalui pembelajaran sejarah yang "terbalik" demikian, maka posisi materi-materi yang terdapat dalam struktur mata pelajaran sejarah bukan hanya sebagai aspek pengetahuan belaka. Materi-materi yang terdapat di dalam pelajaran sejarah dapat menjadi selangkah lebih maju sebagai pandangan gambaran solusi pemecahan masalah-masalah kekinian. Melalui proses pembelajaran sejarah yang demikian, maka diharapkan akan menarik minat, motivasi, dan aktifitas siswa untuk belajar sejarah. Sejarah tidak akan lagi dianggap sebagai pelajaran masa lalu semata, namun lebih dari itu, sejarah akan dianggap sebagai pelajaran yang mampu memecahkan permasalahanpermasalahan sosial kemasyarakatan pada masa kini.

\section{Desain Pembelajaran Sejarah Melalui Pendekatan Regresif Model Problem Based Learning}

Sudah begitu banyak tulisan dan penelitian berkaitan dengan pembelajaran sejarah yang tepat dan sesuai untuk siswa. Jawaban yang paling pasti adalah berbagai tulisan atau laporan penelitian tersebut akan relevan pada situasi khusus yang digambarkan dalam tulisan atau laporan penelitian tersebut. Dalam tulisan ini ditekankan pada bagaimana mendesain pendekatan pembelajaran sejarah yang diintegrasikan oleh suatu model pembelajaran untuk mencapai tujuan terbentuknya siswa dengan pengembangan kompetensi yang mampu berpikir kritis, mampu berkolaborasi, kreatif dan mampu berkomunikasi (lisan maupun tertulis) sesuai dengan tuntutan kompetensi abad XXI.

Untuk menciptakan generasi yang tangguh dan siap dalam menghadapi perubahan jaman, dari sektor pendidikan harus memaksimalkan perhatian dalam dua hal, yaitu pola pikir (mindset) dan kurikulum. Pendidikan sejarah dalam menjawab "tantangan" tersebut memiliki posisi yang sangat penting karena sejarah berperan penting dalam membantu siswa memahami suatu peradaban, membangun moral bangsa, dan memberi penguatan 
perasaan nasionalisme. Lebih khusus lagi pembelajaran sejarah di dalam kelas secara ideal berperan dalam internalisasi nilai-nilai dan pola pikir yang ideal yang mengarahkan siswa menjadi individu yang berkarakter dan warga negara Indonesia yang bangga dan cinta tanah air. Peran pembelajaran sejarah di atas selaras dengan yang dituangkan di dalam pedoman pengembangan silabus dan penilaian mata pelajaran sejarah, yakni:

1) membangun kesadaran peserta didik tentang pentingnya waktu dan tempat yang merupakan sebuah proses dari masa lampau, masa kini, dan masa depan;

2) melatih daya kritis peserta didik untuk memahami fakta sejarah secara benar dengan didasarkan pada pendekatan ilmiah dan metodologi keilmuan;

3) menumbuhkan apresiasi dan penghargaan peserta didik terhadap peninggalan sejarah sebagai bukti peradaban bangsa Indonesia di masa lampau;

4) menumbuhkan pemahaman peserta didik terhadap proses terbentuknya bangsa Indonesia melalui sejarah yang panjang dan masih berproses hingga masa kini dan masa yang akan datang; dan

5) menumbuhkan kesadaran dalam diri peserta didik sebagai bagian dari bangsa Indonesia yang memiliki rasa bangga dan cinta tanah air yang dapat diimplementasikan dalam berbagai bidang kehidupan, baik nasional maupun internasional.

Berpijak dari hal tersebut, maka beberapa penelitian dan kajian selama ini sebagian besar ternyata masih menunjukkan belum tercapainya secara optimal tujuan pembelajaran yang dimaksud. Berbagai fakta justru menunjukkan bahwa adanya kesan umum yang kurang positif dari para siswa tersebut terhadap proses pembelajaran sejarah di kelas. Para siswa sering mengungkapkan bahwa pengajaran sejarah di sekolah cenderung kurang menarik.
Pelajaran sejarah di kelas juga sering dirasakan oleh siswa sebagai uraian faktafakta kering yang berupa urut-urutan tahun dan peristiwa saja. Pelajaran sejarah bahkan sering pula dirasakan oleh siswa sebagai pengulangan terhadap hal-hal yang sama (Widja, 1989). Jika persepsi dan kelemahan pelajaran sejarah tersebut dibiarkan, maka peran dan tujuan pembelajaran sejarah bagi generasi penerus bangsa yang secara ideal ingin dicapai tentu saja hanya akan tetap menjadi suatu angan-angan saja.

Pembelajaran sejarah pada dasarnya memiliki peran penting dalam mengaktualisasikan dua unsur pembelajaran dan pendidikan. Unsur pertama ialah pembelajaran dan pendidikan intelektual, serta unsur kedua ialah pembelajaran dan pendidikan moral bangsa (Isjoni, 2007). Pada unsur yang pertama tersebut, sejarah bukan hanya sebagai pemberian gambaran tentang masa lalu semata, namun juga sebagai upaya pemberian latihan bagi para siswa untuk berfikir kritis, menarik kesimpulan, mencari makna, serta menarik nilai-nilai dari peristiwa sejarah yang telah dipelajari. Melalui latihan berfikir kritisanalitis, para siswa diharapkan akan mampu dalam menghadapi tantangan jaman yang bersifat kontekstual (Widja, 2002).

Oleh karena itu, cukup memiliki dasar untuk dikembangkan model rekonstruksi pembelajaran sejarah yang sejalan dengan karakteristik sejarah itu sendiri. Artinya, perlu dikembangkan pembelajaran sejarah yang terdiri dari unsur kritis, kronologis, perspektif waktu, prinsip kausalitas, serta pemahaman sejarah berdasarkan pendekatan multidimensional (Depdiknas, 2003). Salah satu gagasan yang dapat dijadikan alternatif untuk menaikkan posisi pembelajaran sejarah lebih menarik dan menantang bagi siswa dan guru ialah dengan pembelajaran yang berorientasi pemecahan masalahmasalah kekinian. Melalui pemecahan masalah-masalah kekinian, maka pembelajaran sejarah tidak hanya dianggap sebagai pelajaran masa lalu semata, namun dapat menjadi suatu kajian kritis terkait 
fenomena-fenomena masalah sosial kemasyarakatan masa kini.

Kontekstualisasi permasalahan impor gula dan pandemi Covid-19 dalam pembelajaran sejarah adalah proses mengkontekstualkan peristiwa-peristiwa tersebut menjadi bagian dari materi pembelajaran sejarah.

Secara khusus dalam mata pelajaran Sejarah maupun Sejarah Indonesia pada Kurikulum 2013, memang tidak membahas tentang materi tersebut secara khusus. Namun bukan berarti kurikulum menutup kreativitas pendidik untuk membelajarkan topik tertentu dan mengkontekstualkannya dengan situasi relevan saat ini. Dalam membahas konsep kontekstualitas yang dikaitkan dengan pembelajaran sejarah, Vinco menyebutkan sebagai berikut :

"Konteks berarti berbagai hal yang berkaitan dengan gagasan atau pengetahuan awal seseorang yang diperoleh dari berbagai pengalamannya sehari-hari. Konteks sangat berkaitan dengan lingkungan dan pengalaman kehidupan masing-masing individu. Dalam kaitannya dengan pembelajaran sejarah, ini disebut dengan konteks sosial dan konstruksi sejarah" (Vinco, 2018).

Oleh karena itu pembelajaran kontekstual tidak sekedar proses "connecting" atau menghubungkan, mengaitkan, merelevansikan saja, akan tetapi juga memahami sesuatu sesuai dengan konteksnya.

Kontekstualisasi pembelajaran sejarah memang bukan hal yang mudah dan sederhana untuk dirancang dan dilakukan, tetapi bukan juga sesuatu yang mustahil untuk dilakukan. Secara teknis penekanan utama kontekstualisasi dalam pembelajaran sejarah adalah keterkaitan, relevansi, antara materi pembelajaran dengan kehidupan nyata, antara peristiwa sejarah di masa lampau dengan konteks sosial saat ini serta memahami sesuatu berdasarkan konteksnya. Oleh karena itu pembelajaran sejarah kontekstual dapat dilakukan secara regresif, yaitu mengkontekstualkan situasi saat ini ke situasi atau peristiwa pada masa lampau (mundur ke belakang). Perlu diperhatikan bahwa dalam kontekstualisasi, mengaitkan peristiwa sejarah dengan masa sekarang baik secara regresif, tidak berarti membawa kacamata saat ini untuk memahami peristiwa masa lampau atau sebaliknya. Setiap peristiwa sejarah memiliki konstruksi sosial masing-masing sesuai zamannya, dan hanya dapat dipahami serta dimengerti sesuai dengan konteksnya.

Penyajian desain pembelajaran sejarah dengan pendekatan regresif untuk mengkaji persoalan-persoalan yang bersifat kontekstual akan sangat relevan jika dilakukan dengan menggunakan model pembelajaran berbasis masalah (Problem Based Learning/PBL). PBL menjadi sangat relevan karena kontekstualitas pembelajaran sejarah disajikan dalam bentuk permasalahan-permasalahan terkini yang kemudian dapat dicari data dan informasinya menggunakan pengetahuan sejarah masa lalu dari berbagai sumber.

Dalam merancang desain pembelajaran yang sesuai dengan maksud tulisan ini, ada tiga variabel yang perlu menjadi penekanan khusus : pembelajaran sejarah, pendekatan regresif, dan kontekstualitas. Aspek-aspek yang menjadi sasaran pengembangan desain pembelajaran sejarah ini mencakup penyusunan rencana pembelajaran, pengembangan materi ajar yang sesuai, kegiatan pembelajaran berbasis masalah, serta perancangan instrumen penilaian yang otentik. Secara ringkas konstruksi pembelajaran sejarah dengan pendekatan regresif melalui model pembelajaran berbasis masalah dapat dilihat dalam matriks di bawah ini.

\section{Gambar 1. Matriks desain pembelajaran sejarah yang bersifat kontekstual dengan pendekatan regresif menggunakan model Problem Based Learning}




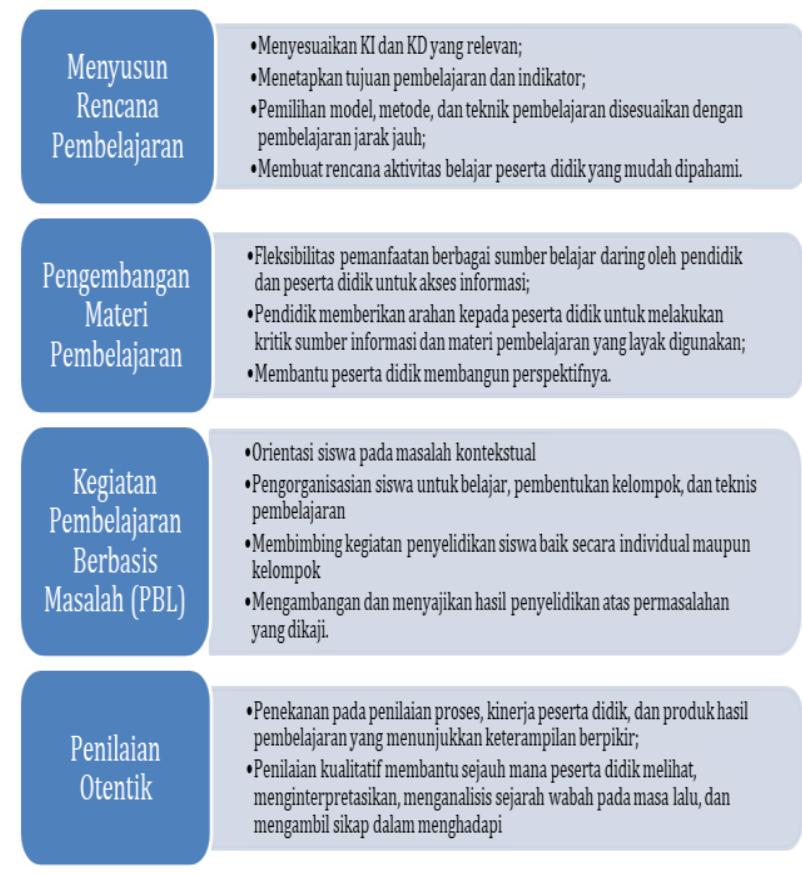

Pada tahap awal, menyusun rencana pembelajaran merupakan tahap yang bertujuan untuk merencanakan, mempersiapkan, menyesuaikan, dan mengkondisikan desain pembelajaran yang akan dilaksanakan oleh guru. Tahap ini meliputi penyesuaian $\mathrm{KD}$ dan $\mathrm{KD}$, tujuan serta indikator (IPK), pemilihan pendekatan, metode dan teknik pembelajaran yang kemudian pada masa pembelajaran jarak jauh juga harus disesuaikan. Perlu diperhatikan bahwa tidak semua KD, Indikator dan materi ajar sesuai untuk diterapkan dengan pendekatan ini. Jadi guru harus mampu mengenal dengan baik karakter dan tuntutan beban mata pelajarannya untuk dibuatkan desain pembelajaran yang bersifat kontekstual, bermanfaat dan memberikan kebermaknaan dalam berbagai sisi kehidupan siswa. Dalam tahap penyusunan juga dapat dibuatkan sejenis LKPD (Lembar Kerja Peserta Didik) dan sumber-sumber belajar yang baik dan menarik untuk melatih sikap mandiri dan kreativitas siswa dalam bekerja secara individual maupun kelompok.

Pada tahap pengembangan materi ajar, guru harus mampu menyajikan permasalahan-permasalahan kontekstual untuk dibahas terlebih dahulu. Materi pembelajaran kemudian ditelusuri dari permasalahan tersebut dengan menyajikan berbagai alternatif bahan ajar yang baik secara mandiri oleh siswa maupun dibantu oleh guru disiapkan secara terencana. Misalnya saja guru menyajikan permasalahan mengenai kondisi minimnya produksi gula di Indonesia saat ini, dengan rencana pendekatan regresif berbasis masalah siswa diajak menelusuri berbagai sumber literature mengenai kejayaan produksi gula di Indonesia pada masa pemerintahan Hindia-Belanda, khususnya pada masa pemberlakuan Cultuurstelsel. Atau jika menggunakan masalah berupa pandemic Covid-19 yang terjadi saat ini, guru dapat mempersiapkan sumber belajar yang menyajikan situasi terkait wabah Black Death yang pernah hampir memusnahkan Eropa misalnya (Janti, 2020), atau bahkan Wabah Kolera yang menimpa dunia secara simultan dan berdampak besar pada kehidupan manusia pada Abad XIX-XX (Ridhoi, 2020). Sedangkan di Indonesia catatan tertua wabah penyakit ditemukan masa pada Klasik (Hindu-Budha) masa pemerintahan Raja Airlangga pada tahun 1006-1042 M (Harriyadi, 2020), hingga pengambilan kebijakan penanganan wabah pada masa Hindia Belanda (Janti, 2020).

Sejarah tidak hanya berisi kisah yang ditulis dalam buku teks atau kurikulum melainkan juga yang dialami (Supriatna, 2019). Peserta didik dapat menuangkan argumen dan perspektifnya mengenai apa yang dialami dan bermakna untuk orang lain. Dalam merancang pembelajaran sejarah menggunakan model pembelajaran berbasis masalah, guru perlu meluaskan pemahaman siswa melalui penyelidikan terhadap permasalahan-permasalahan yang bersifat kontekstual, kemudian dikembangkan sikap yang melatih kedalaman berpikir kritisanalitis agar siswa dapat menemukan signifikansi historis dan menumbuhkan empati historisnya (Amboro, 2019). Tentu saja langkah-langkah yang dilakukan dengan menggunakan model ini sesuai dengan sintaks pembelajaran berbasis masalah, hanya saja menggunakan pendekatan 
pembelajaran regresif dalam penyelidikannya.

Pada tahap penyusunan atau pelaksanaan penilaian yang otentik, guru dapat mempersiapkan berbagai bentuk penilaian. Kurikulum 2013 memberi ruang bagi pendidik untuk untuk melakukan autenthic assessment kepada peserta didik dengan menekankan pada penilaian proses, kinerja peserta didik atau produk yang dihasilkannya, termasuk produk dari keterampilan berpikirnya (Supriatna, 2019). Hal yang perlu diingat tentunya adalah ketuntasan belajar dan ketrampilan berpikir tingkat tinggi (high order thinking skills) peserta didik, tidak selalu dibangun dari banyaknya materi atau fakta sejarah yang diingat, jadi pendidik seharusnya tidak lagi menjadikan habis/selesainya materi sebagai tolok ukur selesainya pembelajaran dan tercapainya tujuan. Dalam penilaian berbasis masalah, guru harus cermat melakukan penilaian proses melalui pemantauan kinerja siswa dalam penyelidikan masalah. Guru tidak boleh terjebak di dalam dikotomi benar-salah. Guru harus mampu memberikan apresiasi terhadap argumentasiargumentasi siswa yang disajikan dengan data dan informasi yang mereka temukan. Penilaian secara kualitatif akan dapat lebih membantu memahami sampai sejauh mana peserta didik melihat, menginterpretasikan, menganalisis pembelajaran sejarah yang siswa lakukan.

Jadi dalam suatu desain pembelajaran, guru secara kreatif dan adaptif dapat mengkreasikan penyajian proses pembelajaran melalui penerapan pendekatan regresif berkolaborasi dengan model pembelajaran berbasis masalah (Problem Based Learning) dalam mengkaji kontekstualitas permasalahan sejarah. Dengan demikian, pembelajaran sejarah menjadi lebih kaya akan metode atau konsep berpikir bagi siswanya dan sedikit demi sedikit siswa akan merasakan kebermanfaatan pembelajaran sejarah dalam kehidupannya.

\section{PENUTUP}

Menyajikan materi sejarah tidak harus selalu melihat masa lalu menuju masa sekarang. Ketika pola pendekatan pembelajaran demikian belum mampu menghasilkan proses belajar yang melatih daya berpikir kritis-analitis siswa maka sangat beralasan untuk disesuaikan, bukan untuk diubah atau diganti melainkan disempurnakan dan dilengkapi.

Menakar kontekstualitas pembelajaran sejarah memang tidak mudah, tetapi bukan mustahil. Perlu kreativitas dan motivasi yang besar dari guru dan juga siswa dalam mengembangkan pembelajaran yang kreatif, inovatif, dan bermakna. Kontekstualitas dimensi ruang dan waktu saat ini bisa dikaji melalui perspektif ilmu (pembelajaran) sejarah. Bagaimana sejarah melihat kontekstualitas saat ini tentu melalui pendekatan dan model yang sesuai bagi guru dan siswa berkolaborasi di dalam kelas maupun di luar kelas.

Pendekatan regresif melalui model pembelajaran Problem Based Learning memberikan peluang bagi sejarah untuk membahas kontekstualitas peristiwa dari dimensi ruang dan waktu. Siswa diajak untuk mampu berpikir kritis-analitis sesuai dengan tahap pengembangan pembelajaran yang dirancang oleh guru. Dalam pengembangan desain pembelajaran sejarah guru perlu menyesuaikan komponenkomponen seperti KI, KD, Indikator dan tujuan pembelajaran yang relevan untuk pembelajaran dengan pendekatan regresif melalui model Problem Based Learning.

\section{DAFTAR RUJUKAN}

Amboro, K. (2019). Kontekstualisasi Pandemi Covid-19 dalam Pembelajaran Sejarah. Yupa : Historical Studies Journal .

Depdiknas. (2003). Kurikulum 2004 SMA: Pedoman Khusus Pengembangan Silabus dan. Jakarta: Dikti Dirjen PDM-DPMU.

Dowling, S. (2020, April 24). How global outbreaks are contained. Retrieved Desember 25, 2020, from BBC: 
https://www.bbc.com/future/article/2 0200422-how-disease-outbreaks-arecontained

Harriyadi. (2020, Oktober 22). Balai Arkeologi Nasional. Retrieved Maret 3, 2021, from Wabah Penyakit dalam Catatan Sejarah di Indonesia: http://arkenas.kemdikbud.go.id/conte nts/read/ article/67ihzv_1586426994/wabahpenyakit-dalam-catatan-sejarah-diindonesia\#gsc.tab $=0$

Isjoni. (2007). Pembelajaran Sejarah pada Tingkat Satuan Pendidikan. Bandung: Alfabeta.

Janti, N. (. (2020, April 11). Penerjunan Tenaga Medis pada Wabah di Hindia Belanda. Retrieved Juni 6, 2020, from Historia.id: https://historia.id/sains/articles/penerj unan-tenaga-medis-pada-wabah-dihindia-belanda-Pzdk0

Nugraheny, D. E. (2020, April 1). Update per 31 Maret: 1.528 Kasus Covid-19, Masyarakat Diajak Saling Beri Edukasi. Retrieved Desember 26, 2020, from Kompas.com: https://nasional.kompas.com/read/20 20/04/01/06293531/update-per-31maret-1528-kasus-covid-19masyarakat-diajak-saling-beri

Pujilestari, Y. (2020). Dampak Positif Pembelajaran Online Dalam Sistem Pendidikan Indonesia Pasca Pandemi Covid-19. ADALAH : Buletin Hukum dan Keadilan, 49-56.

Putri, R. H. (2020, Pebruari 15). WabahWabah Penyakit Pembunuh Massal. Retrieved Juli 22，2020， from Historia.id:

https://historia.id/sains/articles/waba h-wabah-penyakit-pembunuhmassal-P7eL5

Ridhoi, M. A. (2020, Maret 25). Sejarah Pandemi dan Epidemi di Dunia yang Memicu Gejolak Politik. Retrieved
Desember 26, 2020, from Kata Data: https://katadata.co.id/berita/2020/03/ 25/sejarah-pandemi-dan-epidemi-didunia-yang-memicu-gejolak-politik

Supriatna, N. (2019). Pengembangan Kreativitas Imajinatif Abad Ke-21 dalam Pembelajaran Sejarah. Historia : Jurnal Pendidik dan Peneliti Sejarah, 73-82.

Swantoro, P. (2016). Masa Lalu Selalu Aktual. Jakarta: Kepustakaan Populer Gramedia.

Vinco, M. (2018). Kontekstualisasi Kehidupan Masa Praaksara di Indonesia: Analisis Buku Teks Pembelajaran Sejarah. Historia : Jurnal Pendidik dan Peneliti Sejarah, 105-114.

Widja, I. (1989). Sejarah Lokal Suatu Perspektif dalam Pengajaran Sejarah. Jakarta: Depdikbud Dikti PPLPTK.

Widja, I. (2002). Мепuju Wajah Baru Pendidikan Sejarah. Yogyakarta: Lappera Pustaka Utama.

Wisnu, \& SN4JPSFISUNP2019. (2019). Penguatan Pembelajaran Sejarah di Era Disrupsi (Rekonstruksi Pembelajaran Sejarah Regresi). OSF, https://doi.org/10.17605/OSF.IO/ED GAZ. 